\title{
NAUCZANIE DIALEKTOLOGII NA STUDIACH UKRAINISTYCZNYCH NA UNIWERSYTECIE MARII CURIE-SKŁODOWSKIEJ W LUBLINIE
}

\author{
Agnieszka Dudek-Szumigaj \\ Uniwersytet Marii Curie-Skłodowskiej w Lublinie \\ ORCID: 0000-0003-3011-2284
}

\begin{abstract}
Streszczenie. W artykule omówiono miejsce dialektologii w nauczaniu na studiach ukrainistycznych na Uniwersytecie Marii Curie-Skłodowskiej w Lublinie. Przeanalizowano programy studiów w okresie funkcjonowania kierunków: filologia ukraińska i ukrainistyka jako studiów jednolitych magisterskich i dwustopniowych. Omówiono formy kształcenia dialektologicznego, realizowane treści programowe, scharakteryzowano dorobek naukowy wykładowców tego przedmiotu, a także zróżnicowanie grup studenckich pod względem znajomości gwary.
\end{abstract}

Słowa klucze: dialektologia, nauczanie, studia ukrainistyczne, gwara, dialekt

Nauczanie w odniesieniu do każdej dyscypliny badawczej opisującej określoną dziedzinę rzeczywistości jest ,przekazywaniem komuś pewnego zasobu wiedzy, udzielaniem wiadomości, wykładaniem, wdrażaniem do czegoś, przyzwyczajaniem"'. Jak stwierdza Halina Kurek, nauczanie dialektologii jako nauki humanistycznej sprowadza się przede wszystkim do opisu systemu językowego, który jest wytworem myśli człowieka, ale także do informowania o kulturze ludowej reprezentowanej w dialektologii przez słownictwo gwarowe. Jako istota społeczna, człowiek posługuje się różnorodnymi systemami komunikacyjnymi. Należą do nich tzw. języki literackie, czyli systemy znormalizowane, ale także kody nieznormalizowane, będące odmianami języków narodowych. Dialektologia jest właśnie tą dyscypliną naukową, która zajmuje się badaniem i naukowym opisem dialektów i gwar, a więc systemów nieznormalizowanych, funkcjonujących obok języka standardowego ${ }^{2}$.

Przedmiotem badań dialektologii są gwary i ich zespoły - dialekty. Gwara, czyli odmiana języka ogólnonarodowego (etnicznego), pojmowanego w du-

1 H. Kurek, Nauczanie dialektologii $w$ dobie przemian językowych, [w:] Teoretyczne, badawcze i dydaktyczne założenia dialektologii, red. S. Gala, Łódź 1998, s. 357.

2 Ibidem. 
chu strukturalistycznego pojęcia „langue”, definiowana jest jako społecznie wytworzony i uznany, wspólny wszystkim członkom, warstwom i grupom danej społeczności językowej, przekazywany z pokolenia na pokolenie, abstrakcyjny system fonologiczno-gramatyczny, a zarazem zespół norm, będących dyrektywami stosowania tego systemu przy tworzeniu komunikatów językowych (tekstów) w toku porozumiewania się za pomocą znaków językowych (wyrazów). Gwara, obok cech wspólnych z językiem narodowym, odznacza się sobie tylko właściwym zespołem innowacji gramatycznych, obowiązujących w społeczności wiejskiej danego, geograficznie ograniczonego zespołu wsi. Umownym określeniem ugrupowania sąsiadujących ze sobą gwar o określonym zespole jednorodnych, zazwyczaj niewystępujących na terytorium przyległego dialektu cech gwarotwórczych, jest dialekt ${ }^{3}$.

Dialektologia, podobnie jak inne przedmioty historycznojęzykowe, w swoim zakresie odsłania tendencje innowacyjne, kierunki zmian, ukazuje ewolucję języka. Dyscyplina ta pozostaje w ścisłym związku z gramatyką historyczną i stanowi jej kontynuację w zakresie norm regionalnych i relacji do ponaddialektalnej normy literackiej'.

Kurs dialektologii tak umiejscowiony w systemie dyscyplin wykładanych w szkole wyższej pomaga słuchaczom w zrozumieniu miejsca i roli gwar w systemie języka ogólnonarodowego, w uzmysłowieniu im powiązań między dialektami i językiem literackim. Zajęcia z dialektologii ukraińskiej mają na celu zapoznanie studentów z podstawowymi terminami właściwymi tej dziedzinie, zdefiniowanie dialektologii jako nauki z jej przedmiotem, zadaniami, znaczeniem, ukształtowanie umiejętności w zakresie posługiwania się mapą dialektów ukraińskich, analizy tekstów gwarowych, określenia fonetycznych, morfologicznych, leksykalnych cech gwar i dialektów, sporządzania transkrypcji fonetycznej materiałów gwarowych, analizy tekstów gwarowych wraz z określeniem przynależności do gwar i dialektów ${ }^{5}$.

Program kształcenia ukrainistycznego na UMCS w ramach jednolitych studiów magisterskich przewidywał kurs dialektologii ukraińskiej w wymiarze 30 godz. wykładów i 30 godz. konwersatoriów (III rok, semestr 6), kończących się zaliczeniem bez egzaminu. Materiał programowy z tego przedmiotu obejmował następujące zagadnienia: ogólnoteoretyczne problemy dialektologii; fonetyczna, gramatyczna i leksykalna struktura gwar języka

\footnotetext{
K. Dejna, Gwara i jej stosunek do innych odmian języka ogólnonarodowego, [w:] Teoretyczne, dydaktyczne i badawcze założenia dialektologii, red. S. Gala, Łódź 1998, s. 14-15.

4 S. Gala, Dialektologia jako przedmiot dydaktyki polonistycznej, [w:] Teoretyczne, dydaktyczne i badawcze założenia dialektologii, red. S. Gala, Łódź 1998, s. 368-369.

Н. Костів, Проблемні питання викладання діалектології у вищій школі, „Теорія і практика викладання української мови як іноземної” 2017, вип. 13, s. 257-258.

6 Informator o studiach. Filologia ukraińska. Europejski System Transferu Punktów (ECTS), Lublin 2001, s. 27.
} 
ukraińskiego; terminy gwara, narzecze, dialekt; funkcja i geneza elementów systemu gwarowego; archaizmy i innowacje dialektalne; systemy gwarowe (fonetyczno-fonologiczne, morfologiczne, syntaktyczne); słownictwo gwarowe; grupy dialektalne; kryteria klasyfikacyjne według m.in. Mychalczuka, Ziłyńskiego i Żyłki oraz autorów Atlasu języka ukraińskiego; charakterystyka językowa dialektów ukraińskich, geografia cech; dialekt północnoukraiński: gwary wschodniopoleskie, środkowopoleskie i zachodniopoleskie; dialekt południowo-zachodni: gwary wołyńskie, podolskie, nadsańskie, naddniestrzańskie, karpackie (łemkowskie, bojkowskie, zakarpackie, halicko-bukowińskie, pokuckie); dialekt południowo-wschodni: gwary środkowonaddnieprzańskie, słobożańskie, stepowe; metody zbierania i badania gwar?

W nauczaniu dialektologii na studiach ukrainistycznych na Uniwersytecie Marii Curie-Skłodowskiej w Lublinie, oprócz wykładów i konwersatoriów, uwzględniane były także formy zdobywania wiedzy wymagające wyjścia poza sale akademickie, osobistego zaangażowania studentów $\mathrm{w}$ zbieranie materiałów terenowych, a następnie ich samodzielnego opracowania. Możliwości takie dawały adeptom ukrainistyki śródsemestralne praktyki dialektologiczne, uzasadnione naukowo, dydaktycznie i pragmatycznie ${ }^{8}$. Takie ćwiczenia terenowe są istotnym elementem w dydaktyce studiów wyższych: weryfikują zdobytą wiedzę i umiejętności, a jednocześnie odsłaniają nowe zadania: doboru informatora, posługiwania się kwestionariuszem, właściwego stawiania pytań, prowadzenia rozmowy, umiejętności zapisu odpowiedzi ${ }^{9}$. Poza wiedzą językoznawczą niezbędną do dostrzeżenia zjawisk językowych, wyjazdy terenowe wymagają od studentów orientacji w historii kultury materialnej badanego terenu czy znajomości realiów życia wiejskiego. W dobie rozwoju techniki nie bez znaczenia są także aspekty pracy dialektologa $w$ terenie wynikające z pewnej wiedzy informatycznej, jak np. posługiwanie się stacjonarnym i przenośnym sprzętem, oprogramowaniem do cyfrowej rejestracji i obróbki dźwięku ${ }^{10}$. Dla prowadzącego zajęcia są ważnym elementem oceny wiedzy i umiejętności studentów, co jest istotne w dalszym kształceniu dialektologów (na poziomie zajęć seminaryjnych) ${ }^{11}$.

Podczas tych jedno- lub kilkudniowych wyjazdów studenci filologii ukraińskiej mieli za zadanie dokonać samodzielnego zapisu lokalnej gwary, a następnie przetranskrybować nagranie i określić cechy gwarowe ${ }^{12}$. Uczestnictwo

Ibidem, s. 61.

Zob. Н. Костів, op. cit., s. 260.

$9 \quad$ S. Gala, op. cit., s. 369.

10 Ł. Zarzycki, Nowe umiejętności i wymagania stawiane dialektologowi w XXI wieku, „Językoznawstwo" 2011, nr 1 (5), s. 211.

11 S. Gala, op. cit., s. 369.

12 M. Borciuch, Specyfika nauczania ukraińskiego języka literackiego wśród nosicieli gwar ukraińskich, „Teka Komisji Polsko-Ukraińskich Związków Kulturowych” 2008, t. 3, s. 55-56. 
w ekspedycji dialektologicznej i opracowanie zebranego materiału terenowego stanowiło jeden z warunków zaliczenia zajęć z dialektologii ${ }^{13}$.

Istotną rolę $\mathrm{w}$ procesie zdobywania wiedzy dialektologicznej i kształtowania umiejętności w zakresie pozyskiwania materiałów terenowych odgrywa Koło Naukowe Studentów Filologii Ukraińskiej UMCS, powołane w 1993 roku ( $\mathrm{tj}$. w pierwszym roku akademickim funkcjonowania kierunku filologia ukraińska). Ta studencka organizacja naukowa stawia sobie za cel propagowanie wiedzy filologicznej, pogłębianie i kształtowanie zainteresowań badawczych studentów, przygotowywanie ich do samodzielnego rozwiązywania problemów naukowych. Założycielem i pierwszym opiekunem $\mathrm{Koła}^{14}$ był prof. Feliks Czyżewski. Własne zainteresowania badawcze kurator pomyślnie zaszczepiał swoim podopiecznym, rzutowały więc one na profil działalności studenckiej organizacji naukowej. Wśród licznych przedsięwzięć podejmowanych przez Koło znajdowały się wakacyjne studenckie obozy dialektologiczne organizowane na obszarach występowania gwar ukraińskich w Polsce, podczas których studenci poznawali gwarę w praktyce, przeprowadzając wywiady z informatorami, utrwalając je na taśmie magnetofonowej lub nośnikach cyfrowych, a następnie transkrybując i analizując. Wielu członków Koła wykorzystało materiały pozyskane w czasie obozów studenckich do prac magisterskich z zakresu dialektologii, wystapień na konferencjach i sympozjach naukowych i pierwszych samodzielnych publikacji.

W ramach obligatoryjnych praktyk dialektologicznych i obozów organizowanych przez Koło Naukowe słuchacze studiów ukrainistycznych uczestniczyli w krajowych ekspedycjach dialektologicznych, m. in. w: Dąbrowie Białostockiej (1997), Policznej $(2001,2004)$ i Dubiczach Cerkiewnych (1997, 2002) na Białostocczyźnie; w Wyrykach (2001), Lubieniu (2004, 2005), Janówce, Sławatyczach (2005), Kostomłotach, Jabłecznej, Kodniu na południowym Podlasiu; na pograniczu bojkowsko-łemkowskim (2007). Wiele możliwości w zakresie zdobywania wiedzy o gwarach w terenie dały lubelskim ukrainistom międzynarodowe obozy dialektologiczne organizowane przez Katedrę Historii i Kultury Języka Państwowego Uniwersytetu Wołyńskiego w Łucku nad jeziorem Świtaź na Ukrainie (1999, 2000, 2002, 2004); obozy te połączone były z konferencjami naukowymi, w ramach których lubelscy studenci występowali na posiedzeniach sekcji studenckich z referatami. Współorganizatorem wspomnianych przedsięwzięć naukowych adresowanych do młodych badaczy był Zakład Filologii Ukraińskiej UMCS;

\footnotetext{
13 Informator o studiach..., s. 61.

14 Funkcję opiekuna Koła pełnili następnie: dr Ludmiła Siryk, dr Marcin Kojder, dr Anna Choma-Suwała. Od roku 2017 organizacja naukowa studentów funkcjonuje pod nazwą Koło Naukowe Ukrainistów im. Profesora Michała Łesiowa, kolejne opiekunki to mgr Anna Mikiciuk i obecnie mgr Hanna Melnyk.
} 
takie partnerstwo organizacyjne i merytoryczne umożliwiała współpraca między Uniwersytetem Marii Curie-Skłodowskiej i Państwowym Uniwersytetem Wołyńskim w Łucku, sformalizowana zawarciem umowy o współpracę w 2001 roku $^{15}$.

W kolejnych latach funkcjonowania studiów w ramach filologii ukraińskiej (od 2014 roku kierunek funkcjonuje pod nazwą ukrainistyka) wprowadzono istotne zmiany w siatce programowej. Pierwszym niekorzystnym z punktu widzenia kształcenia dialektologicznego krokiem było zredukowanie liczby godzin $\mathrm{z}$ tego przedmiotu (jeszcze $\mathrm{w}$ ramach jednolitych studiów magisterskich) z 60 do 30; z programu studiów usunięto zajęcia wykładowe, pozostawiono konwersatoria. Realizacja przez Polskę Procesu Bolońskiego oznaczała konieczność wprowadzenia dwustopniowego systemu studiów. W opracowaniach programowych takich studiów ukrainistycznych, wprowadzonych na UMCS w roku akademickim $2007 / 2008^{16}$, dialektologia - podobnie jak inne przedmioty historycznojęzykowe (gramatyka historyczna, język staro-cerkiewno-słowiański, historia ukraińskiego języka literackiego) - została potraktowana bez należytego zrozumienia wagi tego kursu dla kształcenia filologów ${ }^{17}$ : w pierwszej siatce programowej filologii ukraińskiej uwzględniającej podział na studia licencjackie i magisterskie przedmiot ten usunięto $\mathrm{z}$ grupy treści kierunkowych ${ }^{18}$.

Możliwość nauczania dialektologii dają obecnie przedmioty do wyboru; rozwiązanie takie jest pewnym kompromisem, nie zapewnia niestety ciągłości kształcenia, którą gwarantuje zapis przedmiotu w siatce programowej studiów, jako że przedmioty do wyboru nie są stałe, ich lista może zmieniać się na początku każdego roku akademickiego, a wykładowcy realizujący dotychczas dydaktykę z zakresu dialektologii nie zawsze w swych obciążeniach znajdują zajęcia $\mathrm{w}$ ramach przedmiotów do wyboru. Zawarty w określeniu bloku przedmiotów wybór oznacza, że w przypadku licznych roczników, na których zajęcia prowadzone są w dwóch grupach (sytuacja taka miała miejsce w cyklu kształcenia na poziomie licencjackim 2015/2016), studenci zapisują

15 Informator o studiach..., s. 18.

16 M. Jastrzębski, Wczoraj, dziś i jutro filologii ukraińskiej w Uniwersytecie Marii Curie-Skłodowskiej w Lublinie, „Teka Komisji Polsko-Ukraińskich Związków Kulturowych” 2010, t. 5, s. 254.

${ }_{17} \mathrm{~W}$ nowej siatce programowej kształcenia ukrainistycznego liczbę godzin z gramatyki języka staro-cerkiewno-słowiańskiego zredukowano z 60 do 30, zmieniając również nazwę przedmiotu na podstawy języka klasycznego (scs.), gramatyka historyczna języka ukraińskiego ze 120 godzin została okrojona do 45, historię ukraińskiego języka literackiego zaś usunięto z programu studiów.

18 Plan studiów obowiązujący od roku akademickiego 2007/2008; kierunek: Filologia ukraińska z drugim językiem słowiańskim, studia I stopnia, studia nienauczycielskie, specjalizacja tłumaczeniowa. 
się na jeden z dwóch zaproponowanych przedmiotów, co oznacza, że połowę rocznika nauka dialektologii ominie. Kolejnym ograniczeniem w zakresie kształcenia dialektologów ukrainistów jest liczba godzin: przedmioty do wyboru obejmują kurs 15-godzinny (przy 60 godz. przewidzianych w pierwszym programie studiów); taki wymiar kursu wymaga pewnej selekcji materiału, co potwierdzają realizowane na studiach ukrainistycznych dotychczas przedmioty do wyboru odnoszące się do problematyki dialektologicznej: Wybrane zagadnienia z dialektologii wschodniostowiańskiej (rok akademicki 2017/2018), Dialektologia ukraińska na tle dialektologii wschodniostowiańskiej (rok akademicki 2016/2017) czy Wybrane zagadnienia z dialektologii i etnolingwistyki stowiańskiej (rok akademicki 2019/2020, 2020/2021).

Jak pisze Katarzyna Węgorowska, dialektologia jest nie tylko działem językoznawstwa, ale też interdyscyplinarnym przedmiotem nauczania, a jej związki z innymi naukami dają szerokie możliwości zarówno dialektologomnauczycielom, jak i ich podopiecznym - uczniom i studentom. W procesie dydaktycznym nie można więc pominąć faktu, że dialektologia wspólistnieje $\mathrm{z}$ wieloma dziedzinami, m.in. z szeroko pojętą kulturą narodową, ludową i regionalną, etnografią i antropologią kultury. Badaczka podkreśla, iż bez znajomości pewnych realiów kultury materialnej czy duchowej nie da się zebrać odpowiedniej leksyki, zrozumieć i omówić zagadnień związanych np. z ludową muzyką, ludowym tańcem, ludowym strojem, regionalnymi kulinariami, obyczajami, obrzędami, świętami, ludowym ujęciem tabu, ludową magią, tradycyjnymi zajęciami i rzemiosłami; potrzebne jest do tego celu poczucie związków z badanym podłożem kulturalnym, umiejętność obserwacji życia $w_{s i}{ }^{19}$. Twierdzenie Nikity I. Tołstoja o tym, iż dialekt ,nie jest wyłącznie lingwistyczną jednostką terytorialną, lecz jednocześnie jednostką etnograficzną i kulturologiczną”20, a na płaszczyźnie relacji język-kultura „uzyskamy dwa paralelne układy: 1. język literacki-kultura elitarna; 2 . mowa potoczna-kultura masowa; dialekty, gwary-kultura ludowa; 4. żargony-kultura tradycyjno-profesjonalna"21, pozwala etnolingwistom uznać gwarę za podstawowy fakt kulturowy społeczności wiejskiej, który współdziała z innymi kodami: obrzędowym, mitologicznym, przedmiotowymi, dlatego też gwara nie może być badana $\mathrm{w}$ oderwaniu od nich ${ }^{22}$. W związku z powyższym w nurcie współczesnych badań interdyscyplinarnych dialektologię łączy się z etnolingwistyką, odwołując się do czynników współtworzących tożsamość grupy i jej we-

\footnotetext{
19 K. Węgorowska, Dialektologia jako interdyscyplinarny przedmiot nauczania, [w:] Dialektologia jako dziedzina językoznawstwa i przedmiot dydaktyki, red. S. Gala, Łódź 2002, s. 542.

20 N.I. Tołstoj, Język a kultura (niektóre zagadnienia słowiańskiej etnolingwistyki), „Etnolingwistyka" 1992, t. 5, s. 19.

21 Ibidem, s. 16.

22 H. Kurek, op. cit., s. 358-359.
} 
wnętrzną zwartość oraz operując badaniem kultur regionalnych, a więc języka i sfery społeczno-kulturowo-obyczajowej mieszkańców wsi ${ }^{23}$.

Potrzeba przyjęcia perspektywy interdyscyplinarnej, sprzyjającej szerszemu oglądowi i pogłębionej interpretacji zjawisk językowych w nauczaniu dialektologii na lubelskich studiach ukrainistycznych wyraża się m.in. w integrowaniu w ramach jednego kursu problematyki dialektologicznej i etnolingwistycznej. Studentom ukrainistyki proponuje się w ramach przedmiotów do wyboru kurs pod nazwą Wybrane zagadnienia z dialektologii $i$ etnolingwistyki słowiańskiej, realizowany dotychczas na III roku studiów licencjackich. Celem wspomnianych zajęć jest kształtowanie wiedzy o podstawowych zagadnieniach z zakresu dialektologii słowiańskiej, w tym dialektologii ukraińskiej, a także o zagadnieniach podstawowych etnolingwistyki, o wspólnych metodach i różnicach w podejściu do przedmiotu badań w dialektologii i etnolingwistyce. Podczas zajęć student zapoznaje się ze zróżnicowaniem regionalnym języków słowiańskich, z podstawowymi pojęciami dialektologii oraz metodami badań dialektologicznych, $w$ tym z metodą geografii lingwistycznej, z dialektami języka ukraińskiego, z regionami historyczno-etnograficznymi, ich kulturą materialną i duchową. Słuchacze kształtują umiejętność dostrzegania zróżnicowania regionalnego języka ukraińskiego i rozumienia jego znaczenia w historii kultury ukraińskiej, są przygotowani do analizy tekstów w celu ustalenia jego cech językowych i przynależności do określonego dialektu, wskazania dialektyzmów w tekstach literatury pięknej i określenia ich cech semantycznych lub gramatycznych ${ }^{24}$.

Jak pokazuje analiza sylabusa przedmiotu, wykładowczyni - prof. Lubow Frolak - zagadnienia dialektologiczne omawia w bardzo szerokim zakresie: dialektologia jako przedmiot dydaktyki oraz dziedzina badawcza; dialektologia a historia języka; dialektologia a etnolingwistyka; język literacki a gwary jako formy istnienia języka; rola gwary w kształtowaniu się ukraińskiego języka literackiego; norma językowa w języku literackim i dialekcie; zróżnicowanie terytorialne języka ukraińskiego; metoda geografii lingwistycznej; atlasy dialektologiczne języków słowiańskich; Ogólnostowiański atlas językowy; Atlas języka ukraińskiego, Atlas gwar Białostocczyzny; ukraińskie słowniki gwarowe; mapy gwar języka ukraińskiego; mapa K. Mychalczuka; Polesie jako region historyczno-etnograficzny i gwary narzecza północnego (w tym gwary Podlasia); narzecze południowo-zachodnie języka ukraińskiego; narzecze południowo-wschodnie ${ }^{25}$.

\footnotetext{
$23 \quad$ Ł. Zarzycki, op. cit., s. 214.

24 Wybrane zagadnienia $z$ dialektologii etnolingwistyki słowiańskiej (sylabus przedmiotu) [źródło internetowe:] https://usosweb.umcs.pl/kontroler.php?_action=katalog2/przedmioty/ pokazPrzedmiot\&kod=H-WZDES-U-1S.5, dostęp: 20.11.2020.

25 Ibidem.
} 
Wśród związków dialektologii z innymi dziedzinami wiedzy i przedmiotami kształcenia akademickiego szczególnie istotne są powiązania tej dyscypliny z gramatyką historyczną. Oksana Kostiw stwierdza:

У процесі викладання діалектології реалізуються основні загальнодидактичні принципи навчання - науковості, системності, наступності, доступності. Особливе значення мають міжпредметні зв'язки, адже виклад матеріалу 3 курсу діалектології пов'язаний передусім зі знаннями, що надає курс історичної граматики. Фонетичні та морфологічні риси, як відомо, $є$ континуантами історичних змін, часто становлять одну з переходових стадій у розвитку голосних чи приголосних. Це стосується, зокрема, різних рефлексів $*$ ь, *o, *е в новозакритих складах, *ы та *i. Тому знання, які отримують студенти $з$ курсу історичної граматики, дають можливість полегшувати сприйняття багатьох понять 3 курсу діалектології ${ }^{26}$.

Integrowanie treści programowych z zakresu dialektologii i gramatyki historycznej jest więc uzasadnione merytorycznie i pragmatycznie. Takie podejście na zajęciach z gramatyki historycznej przyjęli wykładowcy studiów ukrainistycznych - prof. Feliks Czyżewski i dr hab. Marcin Kojder. Stosowanie metod językoznawstwa diachronicznego, wyzyskiwanie danych filologicznych i dialektologicznych naświetla zjawiska językowe w językach: prasłowiańskim, staroruskim, staroukraińskim, współczesnym języku ukraińskim i dialektach tego języka ${ }^{27}$.

Pozytywnym rozwiązaniem w zakresie kształcenia dialektologicznego okazało się wprowadzenie do programu studiów ukrainistycznych od roku akademickiego 2018/2019 w semestrze trzecim studiów licencjackich nowego przedmiotu obligatoryjnego pod nazwą Warianty regionalne języka ukraińskiego $w$ wymiarze 30 godzin zajęć konwersatoryjnych ${ }^{28}$. Jak pokazuje opis kursu, treści dialektologiczne realizowane są na wspomnianych zajęciach przede wszystkim w kontekście zależności między językiem literackim a gwarami jako formy istnienia języka, a celem zajęć jest kształtowanie wiedzy o zróżnicowaniu terytorialnym języka ukraińskiego na ukraińskich terenach etnicznych oraz o wariantach literackiego języka ukraińskiego funkcjonującego na Ukrainie i poza granicami Ukrainy. Treści programowe odnoszą się m.in. do zagadnień wariantywności systemu językowego na różnych poziomach systemowych, w tym do cech wspólnych i różnic zachodzących między wariantami terytorialnymi literackiego języka ukraińskiego na różnych etapach historii

\footnotetext{
26 Н. Костів, op. cit., s. 259.

27 Informator o studiach..., s. 53-56.

28 Plan studiów obowiązujący od roku 2018/2019; kierunek: ukrainistyka; specjalność studiów: Język ukraiński w obsłudze administracyjno-celnej i turystycznej oraz Język ukraiński w biznesie.
} 
języka. Zajęcia umożliwiają studentom rozwój kompetencji interkulturowej poprzez uwzględnienie kontekstu kulturowego w języku, literaturze i kulturze ukraińskiej na poziomach ogólnosłowiańskim i ogólnoeuropejskim, kształtują umiejętność dostrzegania zróżnicowania regionalnego języka ukraińskiego i rozumienia jego znaczenia w historii kultury ukraińskiej oraz umiejętność analizy tekstów w celu ustalenia cech językowych i przynależności do określonego dialektu lub wariantu literackiego języka ukraińskiego ${ }^{29}$.

Realizacja treści programowych obejmujących wiedzę o terytorialnych odmiankach języka ukraińskiego jest możliwa w ramach językoznawczych seminariów dyplomowych i magisterskich. Były one i są nadal realizowane w Zakładzie Filologii Ukraińskiej UMCS, obecnie - po zmianach strukturalnych na uczelni - w Katedrze Językoznawstwa Słowiańskiego UMCS. W ramach tych zajęć powstało wiele prac dyplomowych i magisterskich, opartych na dialektologicznych badaniach terenowych, zwykle prowadzonych przez studentów w miejscowościach, z którymi słuchacze studiów byli związani rodzinnie, zarówno na obszarze Polski (Podlasie, Chełmszczyzna, Łemkowszczyzna, Podkarpacie), jak i Ukrainy (m.in. Polesie Zachodnie, Podole, Huculszczyzna).

Warto podkreślić fakt, iż dialektologia na lubelskich studiach ukrainistycznych była i jest prowadzona przez doświadczonych badaczy gwar o znaczącym dorobku naukowym w zakresie terytorialnych odmianek języ$\mathrm{ka}$. W pierwszych latach funkcjonowania filologii ukraińskiej zajęcia wykładowe i konwersatoryjne prowadził prof. Feliks Czyżewski - autor licznych publikacji na temat gwar ukraińskich z obszaru Polski. Wśród jego najważniejszych prac z zakresu dialektologii wymienić należy monografię pt. Atlas gwar polskich i ukraińskich okolic Włodawy ${ }^{30}$, przedstawiającą zróżnicowanie fonetyczne, morfologiczne i leksykalne badanego obszaru za pomocą metod geografii lingwistycznej; monografię pt. Fonetyka i fonologia gwar polskich i ukraińskich poludniowo-wschodniego Podlasia ${ }^{31}$, w której autor podjął się nie tylko opisu systemu fonetyczno-fonologicznego gwar, określenia ich zasięgów, wskazania różnic w stosunku do innych gwar oraz cech łączących je z innymi dialektami, ale przede wszystkim określenia genezy poszczególnych elementów opisywanych systemów. Kolejna publikacja prof. F. Czyżewskiego (we współautorstwie z prof. Stefanem Warchołem) pt.

\footnotetext{
29 Warianty regionalne języka ukraińskiego (sylabus przedmiotu) [źródło internetowe:] https://usosweb.umcs.pl/kontroler.php?_action=katalog2/przedmioty/pokazPrzedmiot\&prz_ kod=H-WRJU-U-1S.3, dostęp: 20.11.2020.

30 F. Czyżewski, Atlas gwar polskich i ukraińskich okolic Włodawy, ,Rozprawy Slawistyczne" 2, Lublin 1986.

31 Idem, Fonetyka i fonologia gwar polskich i ukraińskich poludniowo-wschodniego Podlasia, „Rozprawy Slawistyczne” 3, Lublin 1994.
} 
Polskie i ukraińskie teksty gwarowe ze wschodniej Lubelszczyzny ${ }^{32}$, stanowi dokumentację stanu mowy dwujęzycznej ludności autochtonicznej wschodniej Lubelszczyzny.

W roku 2001 prowadzenie wykładów z dialektologii powierzono prof. Hryhorijowi Arkuszynowi - ukraińskiemu dialektologowi o bogatym dorobku z zakresu gwar zachodniopoleskich, związanemu z Państwowym Uniwersytetem Wołyńskim im. Łesi Ukrainki w Łucku, przez kilka lat zatrudnionemu na stanowisku profesora UMCS, autorowi m.in. słownika gwar zachodniopoleskich ${ }^{33}$, zbiorów tekstów gwarowych ${ }^{34}$, studium z zakresu słowotwórstwa gwarowego ${ }^{35}$, podręcznika akademickiego do dialektologii ${ }^{36}$.

Zajęcia konwersatoryjne $\mathrm{z}$ dialektologii prowadziła przez lata dr Maria Borciuch; sprawowała również funkcję koordynatora studenckich praktyk dialektologicznych. Jest absolwentką lubelskich studiów ukrainistycznych, wychowanką twórcy filologii ukraińskiej na UMCS - prof. Michała Łesiowa, pod którego kierunkiem przygotowała pracę magisterską pt. Leksyka ukraińskiej gwary wsi Wierzbica w województwie zamojskim. Rozprawę doktorską z zakresu dialektologii pt. Fleksja gwar ukraińskich Hrebennego i wsi okolicznych napisała pod kierunkiem naukowym prof. F. Czyżewskiego. Doktor Maria Borciuch w swojej działalności podejmuje się nie tylko dokumentacji dialektologicznej, ale i popularyzacji wiedzy o gwarach, m.in. za pośrednictwem strony internetowej Ukraińskie gwary karpackie w Polsce, poświęconej gwarom ukraińskim występującym na terytorium obecnej Rzeczypospolitej Polskiej w Beskidzie Niskim (gwary łemkowskie), Bieszczadach (gwary bojkowskie) i południowej części Nadsania (gwary nadsańskie) ${ }^{37}$.

Od kilku lat problematykę dialektologiczną na zajęciach konwersatoryjnych w ramach przedmiotów do wyboru i zajęć seminaryjnych realizuje prof. Lubow Frolak, zatrudniona na stanowisku profesora nadzwyczajnego na UMCS w roku 2003 (wcześniej pracownik Katedry Języka Ukraińskiego Uniwersytetu Narodowego w Doniecku), doświadczona badaczka gwar stepowych, autorka monografii pt. Ukraińskie gwary stepowe Doniecczyzny ${ }^{38}$. Wśród zainteresowań badawczych prof. L. Frolak znajduje się współczesny stan, cechy systemowe i metody badań ukraińskich gwar wschodniostepo-

\footnotetext{
32 Idem, S. Warchoł, Polskie i ukraińskie teksty gwarowe ze wschodniej Lubelszczyzny, „Rozprawy Slawistyczne" 9, Lublin 1998.

33 Г. Аркушин, Словник західнополіських говірок: у 2-х m., Луцьк 2000.

34 Idem, Голоси з Підляшия: Тексти, Луцьк 2007; idem, Голоси з Волинського Полісся: Тексти, Луцьк 2010.

35 Idem, Іменний словотвір західнополіського говору, Луцьк 2004.

36 Idem, Західнополіська діалектологія, Луцьк 2012.

37 Ukraińskie gwary karpackie w Polsce [źródło internetowe:] http://www.dialekt-ua.org/ strona-glowna/autorzy/, dostęp: 20.11.2020.

38 Л. Фроляк, Українські східностепові говірки Донеччини, Дрогобич 2013.
} 
wych; wiele publikacji autorka ta poświęciła także gwarom ukraińskim na terenie Polski ${ }^{39}$.

Na koniec kilka uwag należy poświęcić studentom, którzy jako krąg odbiorców materiału programowego nie są grupą jednorodną. W obejmującym blisko 30 lat okresie istnienia studiów ukrainistycznych na Uniwersytecie Marii Curie-Skłodowskiej w Lublinie uczyły się tu i uczą osoby z różną znajomością języka ukraińskiego, zarówno w jego postaci literackiej czy ogólnonarodowej, jak i w postaci odmian terytorialnych. Przez ponad 20 lat najliczniejszą grupę stanowili Polacy, którzy, poza nielicznymi wyjątkami, nie znali języka ukraińskiego. Drugą pod względem liczebności grupę tworzyli studenci pochodzący z rodzin ukraińskich zamieszkujących przed II wojną światową Łemkowszczyznę, Nadsanie, Podlasie i inne regiony; byli wśród nich potomkowie rodzin ukraińskich przesiedlonych przymusowo w latach powojennych przez władze polskie na Ziemie Odzyskane. Studenci z rodzin o korzeniach ukraińskich, pochodzący zarówno z terenów, gdzie ludność ukraińską stanowią autochtoni (np. Podlasie, Chełmszczyzna, Łemkowszczyna, Nadsanie), jak i z obszarów, gdzie polscy obywatele narodowości ukraińskiej są ludnością napływową, która znalazła się tam nie ze swojego wyboru (np. Mazury, Warmia, Pomorze Zachodnie), wynieśli z domu rodzinnego znajomość języka ukraińskiego w jego odmianie gwarowej. Byli wśród nich i są nadal absolwenci szkół z ukraińskim językiem nauczania, którzy zwykle na wysokim poziomie opanowali ukraiński język literacki ${ }^{40}$. Niektórzy uczniowie z rodzin ukraińskich z obszaru Polski uczęszczali na lekcje języka ukraińskiego na poziomie szkoły podstawowej w ramach tzw. punktów nauczania języka ukraiń-

\footnotetext{
39 Zob. m.in. artykuł L. Frolak w niniejszym tomie.

40 W Polsce nauczanie w języku ukraińskim realizowane jest w liceach ogólnokształcących funkcjonujących w ramach następujących placówek: Zespół Szkół z Ukraińskim Językiem Nauczania w Górowie Iławeckim, woj. warmińsko-mazurskie; Zespół Szkół Ogólnokształcących im. Tarasa Szewczenki w Białym Borze, woj. zachodniopomorskie; Zespół Szkół Ogólnokształcących nr 2 im. Markiana Szaszkewicza w Przemyślu, woj. podkarpackie; Zespół Szkół Ogólnokształcących nr $4 \mathrm{im}$. Bohdana Ihora Antonycza w Legnicy, woj. dolnośląskie. Wymienione szkoły umożliwiają uczniom z rodzin ukraińskich także edukację na poziomie podstawowym.

Edukację na poziomie przedszkolnym i podstawowym zapewnia Zespół Szkół z Ukraińskim Językiem Nauczania w Bartoszycach, woj. warmińsko-mazurskie. W Baniach Mazurskich (woj. warmińsko-mazurskie) i w Zespole Szkół im. Adama Mickiewicza w Bielsku Podlaskim (woj. podlaskie) istnieją klasy z językiem wykładowym ukraińskim; zob. S. Romaniuk, M. Saniewska, Rzadko nauczany język sąsiada, „Języki Obce w Szkole” 2014, nr 4, s. 43. W Bielsku Podlaskim edukację przedszkolną w języku ukraińskim realizuje przedszkole „Leśna Polana”. Języka ukraińskiego mogą uczyć się także uczniowie z Białegostoku i Czeremchy, zob. L. Łabowicz, Nowy rok szkolny z językiem ukraińskim na Podlasiu, „Над Бугом і Нарвою” 2016, nr 6 (148), s. 4-5. Język ukraińskiego można się uczyć także w tzw. punktach nauczania, które są tworzone tam, gdzie liczebność uczniów nie pozwala na utworzenie klas (np. w Warszawie), zob. S. Romaniuk, M. Saniewska, op. cit., s. 44.
} 
skiego, inni zaś w formie czynnej znali tylko swoją gwarę ojczystą. Najmniej liczną grupę studentów tworzyli w tym okresie obywatele Ukrainy ${ }^{41}$.

W kolejnych latach proporcje liczby studentów znających język ukraiński w odmianie gwarowej bądź ogólnonarodowej w stosunku do osób rozpoczynających studia bez znajomości języka ukraińskiego odwróciły się. Analiza list studentów ukrainistyki z poszczególnych roczników pokazała, że od roku akademickiego 2013/2014 najliczniejszą grupą studiujących ukrainistykę byli obywatele Ukrainy, w większości z rodzin o polskich korzeniach - posiadacze Karty Polaka, którzy wykształcenie średnie uzyskali w szkołach na Ukrainie, znają więc ukraiński język literacki, a także wyniesioną ze środowiska rodzinnego gwarę. Stan taki utrzymuje się do chwili obecnej. Mniejszość stanowią studenci pochodzenia ukraińskiego - obywatele polscy oraz Polacy bez znajomości języka ukraińskiego.

Nauczanie dialektologii $\mathrm{w}$ grupach tak niejednorodnych pod względem opanowania języka ukraińskiego, zwłaszcza zaś w kontekście znajomości jego odmian terytorialnych, stawia przed wykładowcami szczególne wyzwania na płaszczyźnie nie tylko przekazu wiedzy, ale i kształtowania postaw wobec gwary jako dziedzictwa językowo-kulturowego, niepozostającego bez wpływu na tożsamość etniczną i narodową. Dotyczy to zwłaszcza podejścia do studentów wywodzących się z rodzin ukraińskich z terenu Polski i odnosi się nie tylko do zajęć z dialektologii, ale także do ćwiczeń z praktycznej nauki języka ukraińskiego. Jak zauważa Maria Borciuch:

Ta młodzież z różnych powodów przeżywa rozterki za sprawą swojej „inności”, kompleksów, a nierzadko i swoistego rozdarcia między tym, co w nich polskie $\mathrm{z}$ racji wychowywania się wśród Polaków, a tym, co w nich ukraińskie. Nauczyciel powinien utwierdzać ich w przekonaniu, że gwara nie jest gorsza odmianą języka literackiego, ponieważ wielu $\mathrm{z}$ nich do tej pory uważało, że w ich domu „rozmawia się po ukraińsku”. A na studiach filologicznych nauczyciel zwraca uwagę, że nie powinni tak mówić”, że „mówią źle”, że „to jest błąd”. Niestety takie sytuacje nie sa jednostkowe i doprowadzają do tego, że student ukrainistyki wraca do domu rodzinnego w przekonaniu, że rodzice i dziadkowie mówią niepoprawnie, zaczyna ich strofować za ,złe” formy i obwiniać, że przez nich ma teraz problemy na studiach. [...] Wśród studentów ukrainistyki z rodzin o korzeniach ukraińskich są także osoby, które nie wyniosły z domu znajomości gwary swoich przodków, ponieważ ich rodzice $\mathrm{z}$ różnych względów nie kultywują już w swoich rodzinach tradycji, w których sami wyrośli. Jednakże wchodząc w dorosłość i poszukując swej tożsamości młodzi ludzie zadają sobie pytania: dlaczego dziadkowie mówią między sobą takim językiem i co to za język, w trakcie nauki PNJU zaś przypominają sobie słowa, frazy, formy, jakimi zwracali się do nich w dzieciństwie dziadkowie i przez to nauka staje się dla nich podwójnie ciekawa, bo z każdym argumentem językowym czy kulturowym utwierdzają się

${ }^{41}$ M. Borciuch, op. cit., s. 54-55. 
w przekonaniu, że „dziwny język” ich przodków nie jest „,mieszanką polskiego i ruskiego”, nie jest „tutejszy”, nie jest „,prawosławny” czy „,chachłacki’, ale jest regionalną odmianą języka ukraińskiego ${ }^{42}$.

W podsumowaniu należy stwierdzić, iż mimo ogólnych niekorzystnych warunków obiektywnych związanych $\mathrm{z}$ nauczaniem dialektologii na lubelskich studiach ukrainistycznych (zmiany programu studiów, fakultatywny charakter zajęć, odejście od praktyk terenowych), studenci otrzymują niezbędne w kształceniu filologicznym treści programowe. O zainteresowaniu gwarami świadczą także wybory słuchaczy w zakresie realizacji problematyki seminaryjnej. Dialektologia jest i pozostanie cennym dziedzictwem kultury ludowej oraz ważną i nieodzownie potrzebną do badań nad gramatyką historyczną i historią języka dziedziną wiedzy, należy więc mieć nadzieję, że nie zabraknie jej w nauczaniu na ukrainistyce.

\section{BIBLIOGRAFIA}

Arkušin Grigorìj. 2000. Slovnik zahidnopolis'kih govìrok: u 2-h t. Luc'k: Veža. [Аркушин Григорій. 2000. Словник західнополіських говірок: у 2-x m. Луцьк: Вежа].

Arkušin Grigorìj. 2007. Golosi z Pidlâššâ: Teksti. Luc'k: Veža. [Аркушин Григорій. 2007. Голоси з Підляшшя: Тексти. Луцьк: Вежа].

Arkušin Grigorìj. 2010. Golosi z Volins'kogo Polissâ. Teksti. Luc'k: RVV Volins'kogo nacìonal'nogo unìversitetu ìm. Lesì Ukraïnki. [Аркушин Григорій. 2010. Голоси з Волинського Полісся: Тексти. Луцьк: РВВ Волинського національного університету ім. Лесі Українки].

Arkušin Grigorìj. 2012. Zahidnopolis'ka dialektologiâ. Luc'k: Volins'kij nacìonal'nij unìversitet ìm. Lesì Ukraïnki. [Аркушин Григорій. 2012. Західнополіська діалектологія. Луцьк: Волинський національний університет ім. Лесі Українки].

Borciuch Maria. 2008. Specyfika nauczania ukraińskiego języka literackiego wśród nosicieli gwar ukraińskich. „Teka Komisji Polsko-Ukraińskich Związków Kulturowych” t. 3: 54-59.

Czyżewski Feliks. 1986. Atlas gwar polskich i ukraińskich okolic Włodawy. „Rozprawy Slawistyczne" 2. Lublin: Wydawnictwo UMCS.

Czyżewski Feliks. 1994. Fonetyka i fonologia gwar polskich i ukraińskich potudniowego Podlasia. „Rozprawy Slawistyczne” 3. Lublin: Wydawnictwo UMCS.

Czyżewski Feliks, Warchoł Stefan. 1998. Polskie i ukraińskie teksty gwarowe ze wschodniej Lubelszczyzny. „Rozprawy Slawistyczne” 9. Lublin: Wydawnictwo UMCS.

Dejna Karol. 1998. Gwara i jej stosunek do innych odmian języka ogólnonarodowego. W: Teoretyczne, badawcze i dydaktyczne założenia dialektologii. Red. Gala S. Łódź: Łódzkie Towarzystwo Naukowe: 13-22.

Frolâk Lûbov. 2013. Ukraïns'kì shìdnostepovì govìrki Doneččini. Drogobič: Posvìt. [Фроляк Любов. 2013. Українські східностепові говірки Донеччини. Дрогобич: Посвіт].

42 Ibidem, s. 55. 
Gala Sławomir. 1998. Dialektologia jako przedmiot dydaktyki polonistycznej. W: Teoretyczne, badawcze i dydaktyczne założenia dialektologii. Red. Gala S. Łódź: Łódzkie Towarzystwo Naukowe: 365-370.

Informator o studiach. Filologia ukraińska. Europejski System Transferu Punktów (ECTS). 2001. Opracowanie: Borciuch M. Lublin: Wydawnictwo UMCS.

Jastrzębski Mateusz. 2010. Wczoraj, dziś i jutro filologii ukraińskiej w Uniwersytecie Marii Curie-Skłodowskiej w Lublinie. „Teka Komisji Polsko-Ukraińskich Związków Kulturowych" 2010, t. 5: 251-255.

Oksana Kostìv. 2017. Problemnì pitannâ vikladannâ dìalektologï u visìj školì. „Teorîâ ì praktika vikladannâ ukraïns'koï movi âk ìnozemnoï’. Vipusk 13: 257-263. [Оксана Костів. 2017. Проблемні питання викладання діалектологї у вищіій школі. „Теорія і практика викладання української мови як іноземної”. Випуск 13: 257263.

Kurek Halina. 1998. Nauczanie dialektologii $w$ dobie przemian językowych. W: Teoretyczne, badawcze i dydaktyczne założenia dialektologii. Red. Gala S. Łódź: Łódzkie Towarzystwo Naukowe: 357-363.

Łabowicz Ludmiła. 2016. Nowy rok szkolny z językiem ukraińskim na Podlasiu. „Над Бугом і Нарвою" nr 6 (148): 3-5.

Plan studiów obowiąujący od roku akademickiego 2007/2008; kierunek: Filologia ukraińska z drugim językiem stowiańskim, studia I stopnia, studia nienauczycielskie, specjalizacja tlumaczeniowa.

Plan studiów obowiazujacy od roku 2018/2019; kierunek: Ukrainistyka; specjalność studiów: Język ukraiński $w$ obstudze administracyjno-celnej i turystycznej oraz Język ukraiński w biznesie.

Romaniuk Switłana, Saniewska Marta. 2014. Rzadko nauczany język sąsiada. „Języki Obce w Szkole" nr 4: 43-47.

Ukrainskie gwary karpackie w Polsce. W: http://www.dialekt-ua.org/strona-glowna/autorzy/. [Dostęp 20.11.2020].

Warianty regionalne języka ukraińskiego (sylabus przedmiotu). W: https://usosweb.umcs. $\mathrm{pl} /$ kontroler.php?_action=katalog2/przedmioty/pokazPrzedmiot\&prz_kod=H-WRJU-U-1S.3. [Dostęp 20.11.2020].

Węgorowska Katarzyna. 2002. Dialektologia jako interdyscyplinarny przedmiot nauczania. W: Dialektologia jako dziedzina językoznawstwa i przedmiot dydaktyki. Red. Gala S. Łodź: Łódzkie Towarzystwo Naukowe: 541-549.

Tołstoj Nikita Iljicz. 1992. Język a kultura (niektóre zagadnienia słowiańskiej etnolingwistyki). „Etnolingwistyka” 5: 15-25.

Wybrane zagadnienia z dialektologii etnolingwistyki słowiańskiej (sylabus przedmiotu). W: https://usosweb.umcs.pl/kontroler.php? action=katalog2/przedmioty/pokazPrzedmiot \&kod=H-WZDES-U-1S.5. [Dostęp 20.11.2010].

Zarzycki Łukasz. 2011. Nowe umiejętności i wymagania stawiane dialektologowi w XXI wieku. „Językoznawstwo” nr 1 (5): 207-215.

\section{TEACHING OF DIALECTOLOGY IN UKRAINIAN STUDIES AT THE MARIA CURIE-SKŁODOWSKA UNIVERSITY IN LUBLIN}

Summary. The article analyses the place of dialectology in teaching in Ukrainian studies at the Maria Curie-Skłodowska University in Lublin. The study programs in the period of the Ukrainian philology and Ukrainian studies as uniform master's studies and two 
cycle-studies were analyzed. Forms of dialectological education and programming content are discussed. The scientific achievements of the lecturers were characterized. The diversity of student groups in terms of the knowledge of the subdialect is discussed.

Key words: dialectology, teaching, Ukrainian studies, subdialect, dialect

\title{
ВИКЛАДАННЯ ДІАЛЕКТОЛОГІЇ НА УКРАЇНІСТИЦІ В УНІВЕРСИТЕТІ МАРІЇ КЮРІ-СКЛОДОВСЬКОЇ В ЛЮБЛІНІ
}

\begin{abstract}
Анотація. У статті обговорено місце діалектології на україністиці в Університеті Марії Кюрі-Склодовської в Любліні. Проаналізовано навчальні програми для спеціальностей: українська філологія та україністика у період функціонування одноступеневої та двоступеневої системи освіти. Обговорено види занять 3 діалектології, реалізовані програми навчальної дисципліни, охарактеризовано науковий доробок викладачів цього предмета, а також неоднорідність студентських груп щодо володіння говіркою.
\end{abstract}

Ключові слова: діалектологія, викладання, україністика, говірка, діалект 
